\title{
Implementation of Hajj with Bailout Funds with the Al Qardh Agreement
}

\author{
Subkhi ${ }^{*}$ \\ ${ }^{*}$ Religious Court Judge
}

\begin{abstract}
.
This study seeks to answer the question of whether it is permissible for someone to register Hajj with bailout funds from a financial institution so that the Hajj can be carried out while the body is still healthy, as well as what factors benefit both parties and are there any difficulties faced by both of them (Bank and service users). This study used a sociological juridical approach. The type of research used was descriptive research, data collection using library documentation methods, observation and interviews. The data analysis used a qualitative descriptive method.

This issue has been answered by the MUI National Sharia Council with fatwa number 29 / DSN-MUI / 2002 regarding the financing of Hajj services by the Islamic financial institution. On that basis, many prospective pilgrims have registered through the haj bailout service of Islamic financial institutions. The form of Hajj bailout services is not a commercial transaction that prioritizes profit as the motivation, but is a service of virtue with the aim of helping people who need help.
\end{abstract}

Key words: hajj; Hajj bailout fund; al qardh wal ijarah; virtue

\section{Introduction}

The pilgrimage is the fifth pillar of Islam which is a once-in-a-lifetime obligation for everyone who is able to do it ${ }^{1}$. Such is the sound of Article 1 Paragraph 1 Chapter 1 of the general provisions of the new Law on Organizing Hajj.

The Hajj Law is a replacement for the old Law, namely Law No. 17 of 1999. The difference with Law No. 13 of 2008, is that in Article 1 Chapter 1 of this General Provision the definition of Hajj is the fifth pillar of Islam which is an obligation for every Muslim who is able to fulfill it.

The addition of the sentence "is a once in a lifetime obligation" in Law no. 13 of 2008 can be understood from two points of view. First, from the basis of Islamic religious law itself, it imposes a burden on the obligations of people who are able to only have one well of life. As explained in the hadith, which means: "O people, Allah has made Hajj obligatory for you, so do Hajj." A man said, Is every year yes Rosulallah? Rosulullah was silent until the man asked three times. Then the Prophet replied "If I said yes, then it will become mandatory and you will not be able to do it." (Narrated by Muslim, Ahmad and Nasa'i) ${ }^{2}$

\footnotetext{
${ }^{1}$ Law No. 13 of 2008 concerning the Implementation of Hajj, Director General of Haj and Umrah Organizers, Jakarta, 2008

2 al Qusyairi, Abi al Husain Muslim bin Hajaj. (1993). Shohih Muslim, Beirut : Dar al Fikr., p. 615
} 
Second, along with the increasing number of prospective pilgrims who register, this new law aims to limit the desire of pilgrims to carry out the pilgrimage more than once in their lifetime so as to provide opportunities for others who have not yet.

It seems that the limitation of the opportunity to carry out the pilgrimage is indeed necessary considering the number of prospective pilgrims is increasing every year. While the haj quota given to Indonesian Muslims has not been added, namely following the decision of the 1987 OIC Summit in Amman Jordan, which is 1/1000 (one thousandth) of the total Muslim population of a country, the number of which is determined annually by the Government of the Kingdom of Saudi Arabia and stated in The MOU between the Government of Indonesia and the Government of Saudi Arabia on the preparation of the Hajj Pilgrimage for the current year ${ }^{3}$. So that in each province there is a varied waiting list, ranging from three years to eleven years.

Carrying out the haj pilgrimage is only required for those who are able (istithoah) only. The notion of being able here includes all aspects that cannot be separated; the main thing is provision, health and travel safety "or with the provisions of existing regulations".

Referring to the opinion of the scholars of fiqh regarding the meaning of Istitho'ah; such as the opinion of Imam Abu Hanifah, Ahmad Ibn Hambal and Imam Malik that what is meant by compulsory for those who are able is 'ala al Fauri (at once) when they have provisions to immediately implement it, while according to Imam Shafi'i it is mandatory for those who are able to mean' ala at tarohi (can be postponed). ${ }^{4}$ Given the very limited opportunities, it can be said that it is impossible for the Indonesian people to follow the opinions of Imam Abu Hanifah, Imam Ahmad Ibn Hambal and Imam Malik. Meanwhile, to follow the opinion of Imam Shafi'i, one must be able to plan properly. This is because the opportunity to perform Hajj is not only determined by the availability of sufficient funds, but more importantly, the portion that can accommodate it; and by observing the applicable rules.

The government policy on Hajj registration explains that registration is carried out throughout the year by applying the first come first served principle according to the portion serial number registered in the Integrated Hajj Computerized System (SISKOHAT) ${ }^{5}$ Ministry of Religion. Based on this system, Hajj registration has a varied waiting list. The speed at which the waiting list is determined by the minimum number of pilgrims in each province is adjusted to the policy of dividing the national quota into provincial quotas using the formula of $1 / 1000$ Muslim population.

Based on Siskohat's data, until now the waiting period for registration has ranged from three years to eleven years. The author thinks, If the way the community prepares for Hajj registration has become a habit that has not changed, surely in the future many people pay a portion (savings) in a healthy state (fit) but when they leave, they are already in a less healthy condition. it could even be that you already got a portion, finally you can't leave because it's already old.

\footnotetext{
3 Ministry of Religion of the Republic of Indonesia. (2008). Petunjuk Teknis Penyelenggaraan Haji Director General of Haj and Umrah Administrators, Jakarta.

${ }^{4}$ Imam Nawawi, Al Majmu 'Syarhil Muhazab, Maktabah Salafiyah, Mainah, p. 103

${ }^{5}$ RI Ministry of Religion, Op.cit, page 5
} 
By paying attention to the Hajj registration system which has an effect on a long waiting list, the Al Qardh agreement becomes an interesting thing to study and develop as a solution in overcoming the problems of the Hajj registration system for those in need. So from the academic anxiety above, the author tries to study and analyze the practice of Al Qardh contract services which the author focuses on Pekalongan Syariah Mandiri Bank. Then the study and analysis conducted by the author in this study, the authors summarize in a title "Implementation Of Haji Worship With Balance Funds (Study Of Implementation Of The Al Qardh Akad In Bank Syari'ah Mandiri, Pekalongan Branch)"

This study aims to identify and analyze the view of Islamic law on the implementation of the Hajj with a registration system using bailout funds with the AlQardh Akad, the factors that benefit both parties and whether there are difficulties faced by both (banks and service users). as well as the practice of implementing the Al Qardh contract, especially in serving prospective pilgrims who need bailout funds at the Pekalongan Branch of Bank Syariah Mandiri

\section{Research Methods}

This research uses a sociological juridical approach. This research includes field research (Field Research). The type of research used is descriptive research; the point of this research is to try to explain the facts based on what is found in the field. The data taken includes primary data and secondary data taken by the method of library documentation, observation and interviews. The data analysis used a qualitative descriptive method.

\section{Result and Discussion}

\subsection{Public Understanding of the Hajj Bailout Law}

The public's understanding of the Hajj bailout law in this study is based on the respondent's knowledge of the religious legal basis (sharia foundation) of implementing the Hajj bailout with the Al Qardh agreement, the source of respondents' understanding of the implementation of the Hajj bailout with the Al Qardh agreement and the respondent's knowledge of the existence of Sharia Council Fatwa. National No. 29 regarding the hajj bailout.

Respondents who participated in Hajj bailout services generally based their understanding and beliefs about the Hajj bailout service on what other people conveyed, in this case the most of which was the trust conveyed by Bank Officers. Then the respondents' trust in local Ulama, especially $\mathrm{KBIH}$ managers and officers of the Ministry of Religion.

The phenomenon of the survey results above was caused by the socialization of Fatwa DSN No. 29 of 2002 which is already one windu ( 8 years old) is still not being implemented. As a result, people do not understand the existence of this fatwa. Departing from the lack of understanding of the existence of Islamic bank service rules, they just followed the Hajj bailout service product based on the opinion of local 
scholars who became a reference for questions about religious issues for the community.

A substantial issue related to the motivation for this Hajj bailout service is to be able to carry out the Hajj while the body is still quite healthy by getting a portion as soon as possible and because there is not enough funds, there is only one way, namely using the Hajj bailout service.

\subsection{Implementation of the Al Qardh Agreement at Bank Syariah Mandiri, Pekalongan Branch}

Steps that must be taken by customers to be able to get BSM haj bailout services are as follows:

a. Understand the procedures and requirements by reading the existing brochures.

b. Prepare funds that must be deposited to BSM according to the rules in the brochure.

c. Coming to BSM with a cover letter for Hajj registration from the Ministry of Religion and the following requirements, among others:
1) Copy of valid KTP (4 sheets)
2) Copy of ID card of husband / wife (4 sheets)
3) Copy of 1 sheet of Family Card
4) Copy of Marriage Certificate 1 sheet
5) 5 sheets of 6000 rupiah stamp 6

Then the prospective customer makes a request for the Hajj registration bailout facility, signs it and submits the application accompanied by the above requirements.

a. Pay the savings for the initial deposit according to the selected bailout amount. If you choose a bailout of Rp. 10,000,000, - deposit of Rp. 10,000,000, - If you choose a bailout of Rp. 15,000,000, - deposit of Rp. 5,000,000, -

b. Paying Mabrur Savings Rp. 500,000, -

c. Paying the Ujrah.

Provisions for bailout Ujrah 10,000,000 - 1 year $=900,000$,

Provisions for bailout Ujrah 15,000,000, - 1 year $=1,600,000$, -

Provisions for bailout Ujrah 10,000,000 - 2 years $=1,300,000$, -

Provisions for bailout Ujrah 15,000,000, -2 years $=2,700,000,-^{7}$

Furthermore, the Bank makes a memorandum of analysis of the hajj bailout financing which contains the problems, the requirements that have been submitted, information on prospective customers, analysis of management / character aspects, analysis of financial aspects and guarantees, the final part is a proposal. ${ }^{8}$ whose contents are as follows:

Based on the description above, we propose that the said financing facility can be approved with the following terms and conditions:

a. Provisions

\footnotetext{
${ }^{6}$ Bank Syariah Mandiri, Mandiri Syariah (Brochure), Jl Merdeka No. 5 Pekalongan

${ }^{7}$ Bank Syariah Mandiri, Loc. Cit.

${ }^{8}$ Laksmana, Yusak. (2009). Panduan praktis Account Officer Bank Syariah, Jakarta: Kompas Gramedia. pp. 209
} 
1) Type of financing: al Qardh

2) Financing limit: Rp. 15,000,000, -

3) Purpose of use: To bail out Hajj registration

4) Duration: 1 year

5) Ujroh: Rp. 1,600,000, -

2. Requirements for signing a financing contract

1) Has signed al-Qardh financing agreement wal ujroh haj bailout.

2) Sign a letter of acceptance (commitment to pay off financing).

3) Submit a power of attorney for savings rights.

4) Signing a power of attorney for Hajj cancellation management

5) Submit resignation letter to the local Ministry of Religion (cancellation of hajj).

That is our proposal, ask for your consideration and decision. Waiting for approval and issuance of BPIH initial deposit amounting to Rp. 20,000,000, - (twenty million rupiah).

Referring to the DSN-MUI fatwa no. 29/2002 / concerning the financing of hajj management by Sharia Financial Institutions, there are two contracts that can be used for financing services for hajj management, namely the Al ljarah and al Qardh contracts.

The definition of Al ljarah (operational lease) is an agreement on the transfer of use rights over goods or services, through payment of rental wages, without being followed by the transfer of ownership (ownership / ownership) of the goods themselves. ${ }^{9}$ Meanwhile, the definition of al Qardh (soft and Benevolent loan) is the provision of assets to other people that can be collected or asked for back or in other words borrowing without expecting anything in return. In classical figh literature, Al Qardh is categorized into tathowu'i or a contract of mutual assistance and not a commercial transaction. ${ }^{10}$

Based on the above understanding and by taking into account the hajj bailout service mechanism rolled out by the Pekalongan Branch of Bank Syariah Mandiri as observed by the author, the haj bailout contract carried out by the Pekalongan Branch of Bank Syariah Mandiri is more towards the al ljarah contract, ${ }^{11}$ the other side that shows the existence of the al Qardh contract needs in-depth analysis: because the social motives that characterize the Al Qardh contract cannot be directly captured by the writer's sense of observation.

Ujrah which means rental wages in sharia law is one of the pillars of ijarah besides there is sighat (contract) there are benefits during the lease period and there are two people (pen institutions.) ${ }^{12}$ who do the contract. Therefore, the Hajj bailout product launched by the Pekalongan Branch of Bank Syariah Mandiri is a service with the ljarah principle.

The principle of al Qardh in classical fiqh literature is aqdu tathowu'i or a contract of mutual assistance and not a commercial transaction. In the DSN-MUI fatwa

\footnotetext{
${ }^{9}$ Sabiq, Sayyid. (1987). Fiqhus Sunnah. Beirut: Daul Kutub al Arabi. p. 183

10 Ibid. 163

${ }^{11}$ National Sharia Council Fatwa No. 9 of 2000, One of the obligations of customers as beneficiaries of the leased goods is to pay rent or wages (ujrah).

12 al Khotib, Shaykh Muhammad al Syarini. (ny). Al Iqna juz 2, Darul Ihyai Kutubil Arabiyah . p. 70
} 
number 29/2002 at point 2, it is explained that if needed, LKS can help pay for BPIH customers by using the al qarh principle according to the fatwa of the National Sharia Council number 19 / DSN-MUI / 2001. This provision is very clear that in relation to the hajj bailout the principle that must be used is the principle of al Qardh. Before drawing conclusions, it is better to make an analysis using the principles of al-Qardh by identifying the existing elements (pillars):

a. Al Qardh is a loan given to customers (muqoridh) who need it.

b. The customer of al Qardh is obliged to return the principal amount received at a mutually agreed time.

c. Administrative fees are borne by customers.

d. LKS can ask for guarantees from customers if necessary.

e. Al Qardh customers can provide additional (donations) voluntarily to LKS as long as it is not agreed by the bank.

f. If the customer is unable to return part or all of his / her obligations at the agreed time and the LKS has confirmed its inability the LKS can;

1) extend the return period or

2) write off part or all of its obligations.

The social values identified through the provisions of the al Qardh contract can be matched with the practice of implementing the Hajj bailout contract at BSM Pekalongan Branch;

a. Hajj bailouts are given to customers who need assistance to meet BPIH costs. Earlier, we have described the motivation of customers to participate in the hajj bailout because they want to quickly get a portion with the aim of being able to carry out the pilgrimage while the body is still quite healthy (still young / not too old), while the funds to redeem a portion of Rp. 20,000,000, - (twenty million rupiah) has not been fulfilled so it needs assistance.

b. there is an obligation to return the principal at the agreed time.

a. The principal returns at the agreed time in the sharia contract are no different from other types of financing products (fund distribution).

c. There is no administration fee, but there is an ujrah. The term ujrah is specific to the principle of ijarah while Al Qardh does not have additional funds that must be provided by the customer to the Bank, but there is an administrative fee which the customer must bear. In a context like this it does not mean that the customer should not give any additions at all, but may make additional contributions as long as it is not required by the Bank / LKS, basically the hadith of the Prophet:

a. It means, "the best person among you is the person who is the best in paying his debts." ${ }^{13}$

d. No collateral is required. Hajj service products are zero risk products, meaning that they do not contain risks, such as pilgrims failing to fulfill obligations that may adversely affect LKS / Bank. Hajj servants have received protection from the Ministry of Religion, namely that the Deposit Recipient Bank is a place to deposit Hajj savings for initial deposits, repayments and a place for BPIH funds to be disbursed for pilgrims who have canceled due to certain reasons. Except for that for

\footnotetext{
${ }^{13}$ Al Bukhori. (ny). Shohih Bukhori, Semarang : Usaha Keluarga. p. 57
} 
pilgrim candidates who violate the agreed agreement, the bank can propose a cancellation based on the power of attorney made when making the work contract.

e. No customer has yet added donations to the bank. Although the principle of al Qardh allows LKS to accept additional donations from customers, based on the results of a writer interview with the marking section of the BSM Pekalongan Branch, it is from this point that the al Qardh principle implemented by BSM can be seen, namely that there are no additional contributions from congregations to BSM who are voluntary and what more determined. This is because the hajj bailout service is only a service of virtue, not a commercial service that aims to make a profit.

f. Options that have not been implemented that relieve customers when economic constraints occur, such as; extend the period of return or write off part or all of its obligations. This is because until now no customer has experienced problems.

g. The sanction for confiscation of assets has not been implemented because the Bank can cancel the hajj portion unilaterally because the person concerned signs a power of attorney to cancel the portion for those who fail to leave.

Sanctions for confiscation of assets are almost unnecessary and or will not occur because the product of the Hajj service is a product of virtue in serving God's guests, who generally have good ethics based on sincere worship motivation.Therefore they have a high commitment to carry out their obligations. in accordance with the agreed contract. If udzur syar'i occurs because the customer is bankrupt, sick, which causes the customer to be categorized as not fulfilling the istitha'ah requirements, the BPIH funds can be withdrawn by applying for the cancellation of the hajj and returning the BPIH to the Ministry of Religion, while the disbursement of BPIH funds will return. at the Deposit Recipient Bank where the Hajj Candidate saves.

From the description above and the results of the author's verification with the BSM Account Officer (Zainal Arifin) ${ }^{14}$ that the implementation of the al Qardh contract for the hajj bailout is carried out when the bailout is disbursed as a virtue agreement (helping people who are going to perform the pilgrimage), however, because Bank Syariah Mandiri has an obligation to pay operational expenses, it is impossible for BSM to carry out al Qardh purely so that in implementing it BSM haj bailouts use the ljarah principle in addition to the al Qardh principle.

The survey results shown in the table above show that the public thinks that the BSM haj bailout product is attractive because the cost is affordable so that it is the choice of most respondents, namely 6 respondents (30\%), two respondents (10\%) interested in joining the service program. Hajj bailout funds due to friends' invitation, then 5 respondents (25\%) gave good assessment and confidence in the credibility of the Bank. ${ }^{15}$

In terms of service satisfaction when participating in the Hajj bailout program, it can be seen that as many as 16 respondents (80\%) rated the service provided when participating in the Hajj bailout program was satisfactory, while 4 respondents (20\%)

\footnotetext{
${ }^{14}$ Results of interviews with Br. Zainal Arifin

${ }^{15}$ List of respondents is attached
} 
were others gave a very satisfactory rating of the services provided through the Hajj bailout program. ${ }^{16}$

Respondents gave a very satisfying assessment because they thought everything was made easier. This easy and fast service was confirmed by the BSM Account Officer, ${ }^{17}$ because the hajj bailout service with the al Qardh agreement is included in the category of virtue agreement, solely helping people who want to carry out the pilgrimage, the service is carried out easily in collaboration with Hajj guidance groups in the Pekalongan area and its surroundings.

Then, from the service pattern that fosters a sense of trust, thereby creating satisfaction and affordability of costs set by BSM, it is known that all respondents / 20 respondents $(100 \%)$ have confidence in BSM because of providing complete explanations about hajj bailout services.

\section{Closing}

Sharia reviews regarding the implementation of Hajj using bailout funds from Islamic banks are legal. The provisions for the implementation of the hajj have received legal legitimacy from the MUI National Sharia Council number 29 / SN-MUI / 2002 regarding the financing of Hajj management by Sharia Financial Institutions. The provisions for the implementation of the hajj bailout may be carried out by the LKS with the al-Qardh principle, namely the principle of providing loans on the basis of providing assistance to people who need help. Apart from the principle of al Qardh, it is permissible to manage Hajj financing with the ljarah principle, namely the lease agreement. The main motivation for customers to join Hajj bailout service products is to quickly get a portion of the Hajj.

The implementation of al Qardh at the Pekalongan Branch of Bank Syariah Mandiri can be explained by the author that al Qardh which is a tathawwui contract with the aim of helping people who need assistance can be seen from the willingness of the Bank to provide loans to complement the lack of funds to pay for the hajj portion. After obtaining approval from the management of the Bank, the customer signs an ijarah (lease) agreement on the use of the beneficial value of the bailout fund received. Rental fees are prepaid based on the agreement. Furthermore, the customer is required to return the principal of the bailout at agreed time, it can be done in installments and or by paying cash before maturity. Generally, customers prefer to pay the bailout principal in installments according to their ability, which is important before maturity.

The stipulation of the National Sharia Council fatwa number 29 / DSN-MUI / 2002 regarding the financing of Hajj management by LKS has given fresh air to people who experience difficulties in the cost of registering Hajj. Therefore, it would be nice if there is an institution that has competence in legal institutionalization to disseminate the fatwa that is needed by the community, so that in the future people carry out a sharia contract based on a solid understanding.

\footnotetext{
${ }^{16}$ List of respondents is attached

${ }^{17}$ Results of interviews with $\mathrm{Br}$. Zainal Arifin
} 


\section{Bibliography}

Law No. 13 of 2008 concerning the Implementation of Hajj, Director General of Haj and Umrah Organizers, Jakarta

al Qusyairi, Abi al Husain Muslim bin Hajaj. (1993) Shohih Muslim, Dar al Fikr, Beirut.

Ministry of Religion of the Republic of Indonesia. (2008). Petunjuk Teknis Penyelenggaraan Haji ${ }_{2}$ Director General of Haj and Umrah Administrators, Jakarta.

Imam Nawawi, Al Majmu 'Syarhil Muhazab, Maktabah Salafiyah, Mainah.

Laksmana, Yusak. (2009). Panduan praktis Account Officer Bank Syariah, Kompas Gramedia.

National Sharia Council Fatwa No. 9 of 2000, One of the obligations of customers as beneficiaries of the leased goods is to pay rent or wages (ujrah).

al Khotib,Shaykh Muhammad al Syarini. Al Iqna juz 2, Darul Ihyai Kutubil Arabiyah.

Al Bukhori, Shohih Bukhori, Semarang : Usaha Keluarga. 